\title{
クリノプチロライトのキャラクタリゼーションと シクロヘキセンの骨格異性化反応
}

（1994年 1 月 5 日受理）

野村正幸・齋藤義一十.中田真一圢 · 森村 恭 郎圢

天然ゼオライトの高付加価值化およびその利用という観点で，秋田県二ツ井産のクリノプチロライト を主成分とする天然ゼオライトについて，化学構造解析と触媒反応を検討した．すなわち，クリノプチ ロライト(FZ) とそれを塩酸処理した試料(HFZ) について固体 NMR，熱量測定などよるキャラク タリゼーションとシクロヘキセンの骨格異性化反応を行った．固体 $\mathrm{NMR}$ では, ${ }^{29} \mathrm{Si},{ }^{27} \mathrm{Al}$ および ${ }^{23} \mathrm{Na}$ を対象核として，各プローブ原子まわりのミクロ環境を，また熱量測定ではアンモニア吸着測定 $(473$ K）により酸性質をそれぞれ検討した．処理する塩酸の濃度の增加にともない，HFZの $\mathrm{Si} / \mathrm{Al}$ 比およ び酸量が増大した．HFZ を触媒として用いた 2-プロパノールの脱水反応速度は酸量に比例した。 また シクロヘキセンからメチルシクロペンテン(MCP) への骨格異性化反応では, 酸量の増加にともないメ チルシクロペンタン, 芳香族炭化水素が增加し，MCP 収率が減少した．比較のため用いた HZSM-5 触媒では芳香族炭化水秦のみを与えた。

\section{1 緒言}

天然ぜオライトはイオン交换能，分子ふるい能を有する三次元 網目構造のアルミノケイ酸塩であるが，カス吸収剤や水処理郕， 土墱改良郕, 飼料混合郕などとして，農・畜産業，工業の分野 でおよび一部民生用として各方面で利用されている，わが国で 現在採掘・市眅されている天然ゼオライトはおむにその主成分が クリノブチロライトないしモルデナイであり1，それらの高度 利用技術開発の試みがいくつかなされている233)。 また，上り付 加価值の高いと考えられる触媒としての利用についてもこれま で，いくつか報告がある、例えば, メタノールの脱氷)，キシレ ンの異性化 ${ }^{5) 6}$, ベンゼンの水莱化 ${ }^{6)}$, トルエンの不均化吕, エチ ルヘンンセンの分解6)，スチレンの重合7)，シクロヘキサノールの 脱水8), メタノールから低級オレフィンの合成910)などがある.

一方，クリノブチロライトの特敬としては，合成が難しい高シ

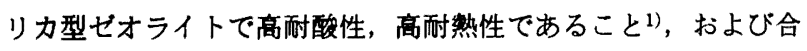
成ぜオライトに比して格段に廉価であることなどが挙げられる。 さらに, クリノプチロライトは結晶学的・鉱物学的に研究が進め られているヒューランタイイと同族でありその骨格構造は同一と 考えられる ${ }^{11)}$ 。したがって, 品筫の均一化, 適切な化学処理お よび触媒としてのキャラクタリゼーションなどが十分になされる ならは， 将来的に工番触媒としての利用の可能性むあると考え

大館网鳴高等学校, 017 大館市金坂後 6

†秋田大学教育学部, 010 秋田市手形学園町 1-1

\#千代田化工建設株式会社総合研究開発センター，221 横 浜市神奈川区守屋町 3-13
る. 天然せオライトの高純度化については, 秋田県二ッ井産クリ ノプチロライト(以下 FZ と略記する) の高品質化が吉田ら2)によ り，粉碎·分級操作を行うことによって，陽イオン交換容量 (CEC) が $195 \mathrm{meq} / 100 \mathrm{~g}$ (純度 92\%) の高純度ゼオライト粉か 得られている. 一方, 著者ら ${ }^{12)}$ は先にメチルシクロペンテン類 （以下 MCP と略記する）を得るために，化学処理されていない $\mathrm{FZ}$ を触媒としてシクロへキセンの骨格異性化反応を行った，そ の結果, 活性アルミナや数種の合成せオライトに比較してより高 収率で MCP が生成した，MCP は天然香料のシクロテン, 生理 活性物筫であるピレスロイド（除虫菊成分）のようなメチルシク ロペンテン誘染体などへの出発物貿となることから, 有機合成化 学的に重要な物質である.

本報では異なる湲度の塩酸で化学処理した FZについて, 結晶 構造, セオライト骨格の化学構造および酸性質に関してキャラク タリセーションを行らとともに, それらを触媒として, アルコー ルの脱水反応およびシクロヘキセンの骨格異性化反応を行った. そして，とくに酸性筫とシクロヘキセンの骨格異性化反応特性と の関係について考察を加えた。

\section{2 実験}

\section{1 試料}

クリノプチロライトを主成分とする天然ゼオライトを $18 \sim 35$ メッシュにそろえた試料(FZ) とそれを化学処理した 9 試料,さ らに比較のために合成ぜオライト 1 種を対象とした。化学処理 は FZ $100 \mathrm{~g}$ を0.1, $0.2,1.0,2.0,6.0,12 \mathrm{~mol} / \mathrm{dm}^{3}$ の各濃度の㙁酸 $200 \mathrm{ml}$ でそれぞれ室温で 2 週間放膡後, 塩化物イオンの溶出か 
確認されなくなるまで十分に水洗して趷燥後, $703 \mathrm{~K} て ゙ 2$ 時間 焼成した。各塩酸処理濃度に対応する各試料をそれぞれ0.1一 HFZ, 0.2-HFZ, 1.0-HFZ, 2.0-HFZ, 6.0-HFZ, 12-HFZ とする. これらをキャラクタリゼーションと触媒反応の検討対象とした. さらに塩酸処理と同じ条件で塩化アンモニウム処理した試料 $\left(0.2-\mathrm{NH}_{4} \mathrm{FZ}, 2.0-\mathrm{NH}_{4} \mathrm{FZ}\right), \mathrm{FZ}$ を蒸留水で塩化物イオンの溶出 が確認されなくなるまで十分に水洗した後に塩酸処理と同一条件 で処理した試料(NFZ) および合成せオライトとして HZSM5 ( $\mathrm{Si} / \mathrm{Al}$ 原子比が 25) を触媒反応の対象とした.

\section{$2.2 \times$ 線回折}

粉末 X 線回折 (XRD) は理学電機製 X 線回折計で行った. 線 源は $\mathrm{Cu} K \alpha$ 線, 加速電圧 $35 \mathrm{kV}$, 電流 $20 \mathrm{~mA}$.

\section{3 蛍光 $X$ 線分析}

$\mathrm{Si}, \mathrm{Al}$ の元䇣分析は蛍光 X 線分析 (XRF) によった。装膡は PHILIPS PW-1400システムで，ガラスビード法で前処理し，検 量線法によって定墨した.

\section{4 固体 NMR}

固体高分解能 NMR（以下固体 NMR とする）の測定は JEOL JNM-GX270 FT-NMR 装圆に固体 CP/MAS ユニットを取り付 けたシステムで行った。試料はDelrin 樹脂製(キャップは Teflon 製) の試料管に約 $0.3 \mathrm{~g}$ を密に充填して54.70 のマシック 角(Magic Angle Spinning: MAS) で $4 \mathrm{kHz} て ゙$ 回転させた状態で 測定した．用いたパルス系列は ${ }^{1} \mathrm{H}$ デカップリングを伴らシング ルパルスで，交差分極(Cross Polarization: $\mathrm{CP}$ ) 法は併用しなか った. なおすべての試料についてあらかじめ水和処理を十分に施 して測定した ${ }^{13)}$

2.4.1 ${ }^{29} \mathrm{Si}-\mathrm{NMR}$ : 観测周波数 : $53.7 \mathrm{MHz}$, 䚁測スペクトル 幅 : $20 \mathrm{~Hz}$ ，データポイント : $8 \mathrm{~K}$, パルス幅 : $5.5 \mu \mathrm{s}$, パルスの 繰り返し時間: $7 \mathrm{~s}$, 積算回数: $4000 \sim 8000$ 回, LB : $12 \mathrm{~Hz},{ }^{29} \mathrm{Si}$ 化学シフトの外部基準はシリコーンコムを二次(外部) 基準（テト ラメチルシランよりー22.33 ppm）とした.

2.4.2 ${ }^{27} \mathrm{Al}-\mathrm{NMR}$ : 観測周波数 : $70.4 \mathrm{MHz}$, 観測スペクトル 幅 : $50 \mathrm{kHz}$, データポイント : $8 \mathrm{~K}$, パルス幅 : $4.5 \mu \mathrm{s}$, パルス の繰り返し時間 : $5 \mathrm{~s}$, 稓算回数 : 400 800 回, LB : $12 \mathrm{~Hz},{ }^{27} \mathrm{Al}$ 化学シフトの外部基準は $\mathrm{AlCl}_{3}$ 水溶液 $\left(1 \mathrm{~mol} / \mathrm{dm}^{3}\right)$ の静止スペ クトルのセンターピークを $0 \mathrm{ppm}$ とした.

2.4.3 ${ }^{23} \mathrm{Na}-\mathrm{NMR}:$ 観測周波数: $71.5 \mathrm{MHz}$, 観測スペクトル 幅: $50 \mathrm{kHz}$, データポイント : $8 \mathrm{~K}$, パルス幅 : $4.5 \mu \mathrm{s}$, パルス の繰り返し時間: $5 \mathrm{~s}$, 穔算回数: 400 800 回, LB : $12 \mathrm{~Hz}$, ${ }^{23} \mathrm{Na}$ 化学シフトの外部基準は $\mathrm{NaCl}$ 水溶液 $\left(1 \mathrm{~mol} / \mathrm{dm}^{3}\right)$ の静止 スペクトルのセンターピークを $0 \mathrm{ppm}$ とした.

\section{5 アンモニア吸首による熱固測定}

熱量測定は東京理工製 HAC-450G 熱計で行った，試料 1.5 $\mathrm{g}$ を $723 \mathrm{~K} て ゙ 1$ 時間加熱し，秤量後測定用セルに移した。測定前 処理として $673 \mathrm{~K}, 1 \times 10^{-3} \mathrm{~Pa}$ で 4 時間排気した後， $473 \mathrm{~K}$ の佰 温槽に設㯰して18〜24 時間後吸着測定を行った. 1 回めたり 10〜30 $\mu \mathrm{mol} / \mathrm{g}$ のアンモニアカスを逐次試料管に尊入して，その 時々の吸着熱と累積吸着熱量を求めた。

\section{6 触媒反応装置および操作}

2.6.12-プロパノールの脱水反応 : 2-プロパノールの脱水反 応はパイレックスガラス符易流通管式反応装㲊を用いて行っ た. 触媒 $10 \mathrm{~g}$ を反応管 $(10 \mathrm{~mm} \phi \times 200 \mathrm{~mm})$ の中心部に入れ，
上下を石英ガラスで固定し， $673 \mathrm{~K} て ゙ 3$ 時間保持した後，温度 を $543 \mathrm{~K}$ をで下げて, $0.5 \mathrm{ml}$ の2-ブロパノールを反応管上部よ り滴下，導入して発生するカスス(プロピレン) 且を反応管下部の 冷却トラップロに付したガスピュレットで測定した.

2.6.2 シクロヘキセンの骨格翼性化反応: 反応は前項と同様 な形式の装置で行った. 触媒 $10 \mathrm{~g}$ を反応管 $(14 \mathrm{~mm} \phi \times 500 \mathrm{~mm}$ ) 中心部に入れ, 公索気流中 $703 \mathrm{~K} て ゙ 3$ 時間前保持した啳, 同温 度で反応させた．シクロへキセンは一定温度に保ったフラスコ

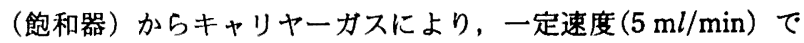
反応管へ尊入した，反応生成物はドライアイスーアセトンで冷却 したトラップに捕集した.

\section{7 反応生成物の分析}

2.7.1 ガスクロマトグラフィー (GC) : GC 测定はヒュレット パッカード(HP) 社製 5880A ガスクロマトグラフィーで行った. カラム : スペルコ社製 SPB-1 溶融シリカキャピラリーカラム 60 $\mathrm{m} \times 0.25 \mathrm{~mm}$ (膜手 $0.25 \mu \mathrm{m}$ )，カラム温度 : $283 \mathrm{~K}$ で 10 分間保 持した後 $323 \mathrm{~K}$ まで年温し，さらに $323 \mathrm{~K} / \mathrm{min} て ゙ 523 \mathrm{~K}$ まで年 温し10 分間保持した. 注入部温度: $423 \mathrm{~K}$, キャリャーガス(流 旦) : $\mathrm{He}(1.4 \mathrm{ml} / \mathrm{min})$, 検出器 : FID.

2.7 .2 ガスクロマトグラフィー/省年分析 (GC/MS) : GC/ MS 湘定は HP 社製 5710 ガスクロマトグラフィーを俌えた JEOL DX-300ガスクロマトグラフィー/量分析計で行った. $\mathrm{GC}$ 部の測定条件は前項の $\mathrm{GC}$ 測定条件と同棣. MS 部の測定条 件は以下のとおりである. イオン化法 : EI 法, イオン源温度 : $443 \mathrm{~K}$, セパレーター温度 : $473 \mathrm{~K}$, スペクトル解析のためのラ イブラリー : NBS パブリックライブラリー.

\section{3 結果亡考察}

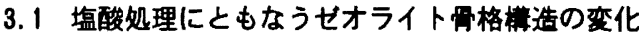

二ツ井産ゼオライト(FZ) はクリノプチロライトを約 $80 \%$ 含 む ${ }^{14)} \mathrm{CEC}$ の高いゼオライトである1).この FZ を酸処理すると処 理港度の增加にともない, アルミニウムの溶出具が增加するこ と，低濃度領城ではナトリウムが急湤に减少して水案イオン濃度 が增加するが，カルシウムは交換されにくく，マグネシウムはほ とんど交換されないことが知られている14). 酸処理にとむなう クリノプチロライトの結晶構造の变化は酸の種類, 灌度, 温度な との処理条件により異なる ${ }^{14) 15)}$ が，X 線回折の検討から，アル ミニウムの溶出致が $12 \%$ までは結晶構造は維持され，それ以上 では粠造破壤が起こるとされている14).

3.1.1結晶構造および Si/Al 比：因1にFZおよび0.5$\mathrm{HFZ}$ 12-HFZ の XRD パターンを示す. FZ と比較して0.5HFZでは変化は喼められない，2.0-HFZでわずかな変化が認め られるが，クリノブチロライトの結晶構造は維持されているとい える，6.0-HFZで次第にその結晶棈造が崩れていき，12-HFZ では明確な棈造破壤が起こっている，表 1 には XRF 表 1 から求 めた $\mathrm{Si} / \mathrm{Al}$ 原子比の变化を示す. 塩酸処理濃度の增加にともない クリノプチロライト骨格からのアルミニウムの容出が進み $\mathrm{Si} / \mathrm{Al}$ 比が増大した. 2.1項で述べたように, 塩酸処理後, 十分水洗し ているので, 脱アルミニウムにより溶出した成分は系内に残存し ないといえる．したがって表 1 で $\mathrm{Si} / \mathrm{Al}$ 比の增大はすなわち零 格からの脱アルミニウムの程度を表すことになる.なお $\mathrm{Si} / \mathrm{Al}$ 比

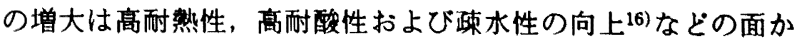




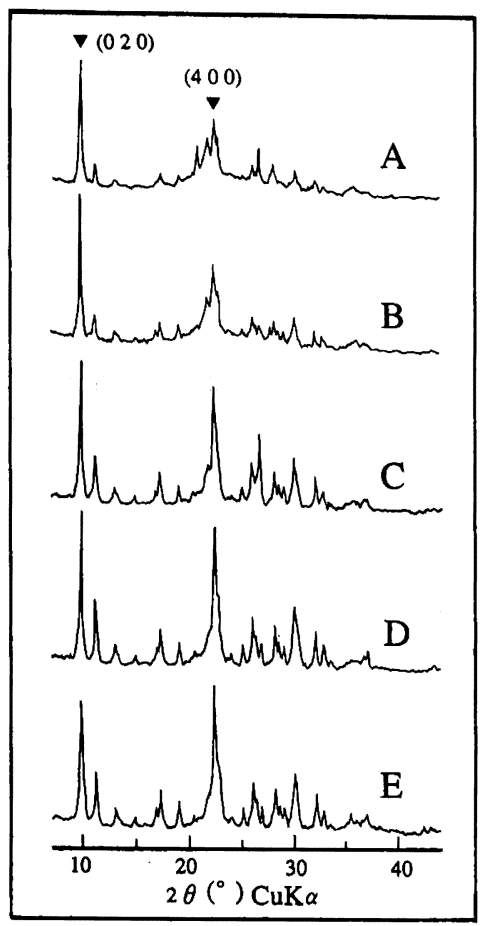

Fig. 1 X-Ray diffraction patterns

A: FZ, B: 0.5-HFZ, C: 2.0-HFZ, D: 6.0-HFZ, E: 12HFZ

$\nabla$ : Attributed to clinoptilolite

Table $1 \mathrm{Si} / \mathrm{Al}$ Atomic ratio determined by XRF for clinoptilolite and chemically treated samples

\begin{tabular}{lr} 
Samples & $\mathrm{Si} / \mathrm{Al}$ \\
\hline $\mathrm{FZ}^{a)}$ & 5.0 \\
$\mathrm{NZF}^{(b)}$ & 6.2 \\
$0.5-\mathrm{HFZ}$ & 6.5 \\
$2.0-\mathrm{HFZ}$ & 8.0 \\
$6.0-\mathrm{HFZ}$ & 12.0 \\
$12-\mathrm{HFZ}$ & 14.9
\end{tabular}

a) Without $\mathrm{HCl}$ treatment.

b) Treated with water at room temperature for 2 weeks.

らは触媒として一般に望ましい性質を付与することが知られてい る.

3.1 .2 固体 NMRによる化学棈造解析 ${ }^{17)}$ : 図 2 K FZ と0.5-

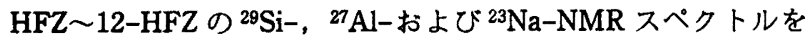
示す. ${ }^{29} \mathrm{Si}-\mathrm{NMR}$ スペクトルでは塩酸処理浱度の增大にともなっ て脱アルミニウムが進行し(表 1$), \mathrm{Si}(n \mathrm{Al})(n=0 \sim 4)$ の配位形 態において $n=0$ により近い配位形態に起因するピーク成分の增

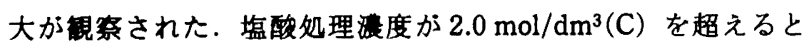
明らかにスペクトルに変化が見られ XRD の結果と合わせ考える と,クリノブチロライト骨格の $\mathrm{Si}$ と Al 原子の配位秩序に顕著な

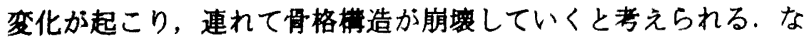
おクリノブチロライトに成する ${ }^{29} \mathrm{Si}-\mathrm{NMR}$ スペクトルのピーク の带属に成しては, Nakata ら ${ }^{18)}$ により提唱されているが， $\mathrm{Al}$ 原 子の $\mathrm{Tn}$ サイトへの分布なども含め現在さらに詳細に検討中であ

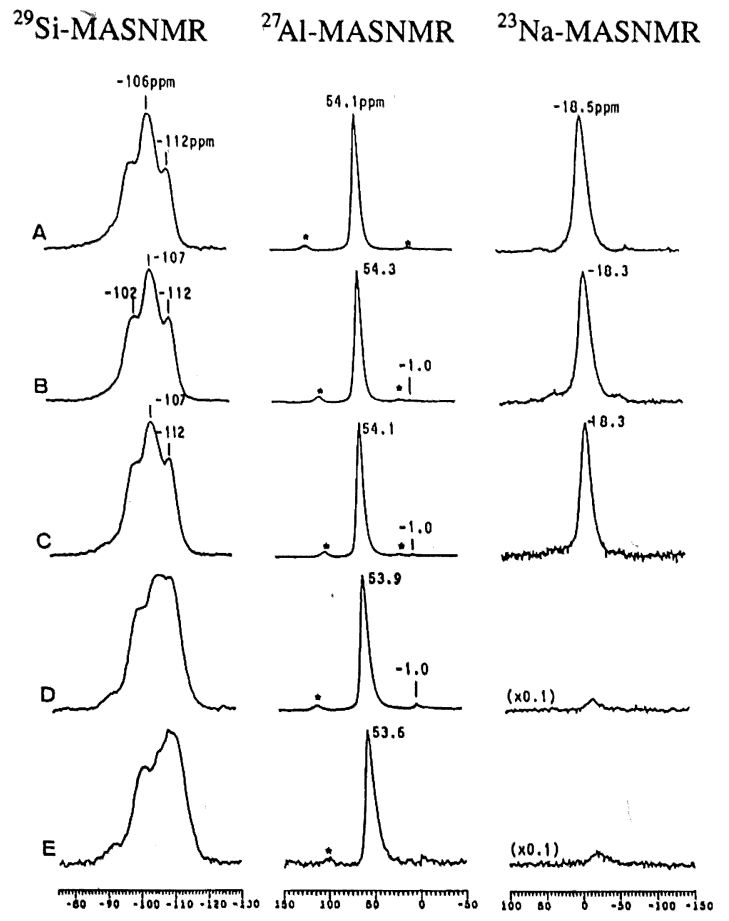

Chemical shift (ppm)

Fig. $2{ }^{29} \mathrm{Si}-,{ }^{27} \mathrm{Al}-$ and ${ }^{23} \mathrm{Na}-\mathrm{MASNMR}$ spectra A: FZ, B: 0.5-HFZ, C: 2.0-HFZ, D: 6.0-HFZ, E: 12HFZ

*: Spinning sidebands

る.

次に ${ }^{27} \mathrm{Al}-\mathrm{NMR}$ スペクトルではすべての試料で-54 ppm 付近 に骨格の形成にあずかっている四配位の $\mathrm{Al}$ ( $\mathrm{Al}$ (tet) と略す) の ピークが観察された．FZでは骨格外の六配位の $\mathrm{Al}$ ( $\mathrm{Al}$ (oct) と 略す）のピークは認められない．塩酸処理された HFZでは， - $1.0 \mathrm{ppm}$ 付近にわずかに $\mathrm{Al}$ (oct) のピークが羿められたが， 大部分は水洗過程で系外に溶出していることがわかる. 塩酸処理 濃度の増加にとむない $\mathrm{Al}$ (tet) のピークの吸収線幅は図 3 のよ うに変化する. ゼオライトの ${ }^{27} \mathrm{Al}$ 核のピークの線幅の広がりは， おもに二次の核四極相互作用が原因であることが多い19). 本結 果の ${ }^{27} \mathrm{Al}-\mathrm{NMR}$ スペクトルの場合も固体 NMR の新しい測定手 法である，二重回転法(Double Rotation: DOR) によれば複数の $\mathrm{Al}$ (tet) 種に起因するピークを含む可能性む予想され，線幅と構 造との関係を一義的に議論することはむずかしい，しかし図 3 からいえることは，塩酸処理濃度の増加による脱アルミニウムの 進行にともない，セオライト骨格の残存する $\mathrm{Al}$ 原子まわりが処 理前に比べてより非対称なミクロ環境ないしは不均質な状態に变 化しているということであろう.

${ }^{23} \mathrm{Na}-\mathrm{NMR}$ スペクトルではすべての試料についてー18 ppm 付 近にピークが観察された．6.0-HFZ および12-HFZではほとん どの $\mathrm{Na}^{+}$は $\mathrm{H}^{+}$と交換し，残存する $\mathrm{Na}^{+}$はわずかである.この ことは先に鳥居ら ${ }^{14)}$ がクリノプチロライト中の $\mathrm{Na}^{+}$が低濃度の 酸により容易にイオン交換するとした結果と矛盾しない。

なお ${ }^{27} \mathrm{Al}(I=5 / 2)$ や ${ }^{23} \mathrm{Na}(I=3 / 2)$ のような核は，核四極相 


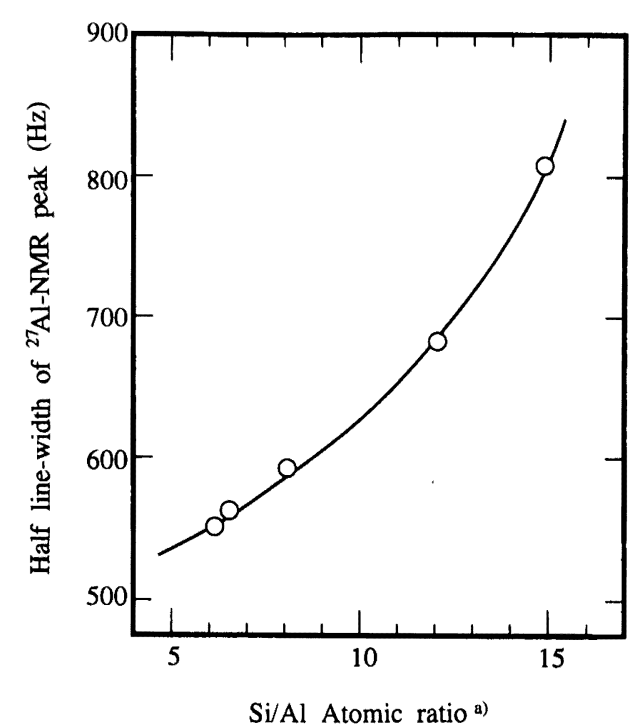

Fig. 3 Half line-widths of ${ }^{27} \mathrm{Al}-\mathrm{NMR}$ peaks as a function of $\mathrm{Si} / \mathrm{Al}$ atomic ratio

a) Determined by XRF

互作用のために線幅が広がることが多く, $\mathrm{NaCl}$ のような対称性 の良い化合物以外は MAS だけでは二次の相互作用を消去できな いことが多い。したがって見かけ上 1 本の均一なピークに見え ても複数の成分からなることもある. その場合, DOR やダイナ ミック回転角法(Dynamic Angle Spinning: DAS) でピークの構 成成分数を見極める必要がある ${ }^{19)}$. 今後の課題としたい.

\section{2 酸 性 酶}

塩酸でゼオライトを処理した場合，骨格のアルミニウム原子の 離脱による酸量, 酸強度の低下を招くことがある ${ }^{16)}$ 。一方, 適 度な条件でゼオライト細孔内の金属イオンをプロトン交換すれ ば, みかけの細孔径の扗大とともに, 酸量または酸強度の増大, 制御が可能になる ${ }^{9115)}$ 。ここでは FZを室温で塩酸処理して ${ }^{23} \mathrm{Na}-\mathrm{NMR}$ でゼオライト細孔内の Na イオンの状態(存在量) を 検討しながら,プロトン交換を行った.

図 4 にいくつかの $\mathrm{HFZ}$ および比較のための $\mathrm{NH}_{4} \mathrm{FZ}$ のアンモ ニア吸着による熱量測定の結果を示す. いずれむ処理滥度の増大 にともない酸量の増加がみられた．本結果からこれらの試料は累 積吸着量の增加にともない微分吸着熱量がなたららかに减少してお り，酸強度分布の広いゼオライトであることがわかった ${ }^{16)}$. 表 2 に微分吸着熱量が $80 \mathrm{~kJ} / \mathrm{mol}$ 以上の值を化学吸着熱量(すなわ ち酸量） ${ }^{20)}$ として求めた結果を示す。相対的に $\mathrm{NH}_{4} \mathrm{FZ}$ が $\mathrm{HFZ}$ より酸量が大きいのは脱アルミニウムの影牟が少ないことによる と考えられる.

\subsection{2 -プロパノールの脱水反応}

図 5 に2-プロパノールの脱水反応速度とクリノプチロライト （FZ）およびそれを化学処理した試料の熱量測定による酸量の関 係を示す. 2-プロパノールの脱水反応速度は触媒の酸䁷に比例 することがわかった。

\section{4 シクロヘキセンの骨格異性化反応}

3.4.1 シクロヘキセンからメチルシクロペンテン類の生成 : Adkins ら ${ }^{21)}$ はシクロヘキセンを加熱したアルミナを用いて骨格

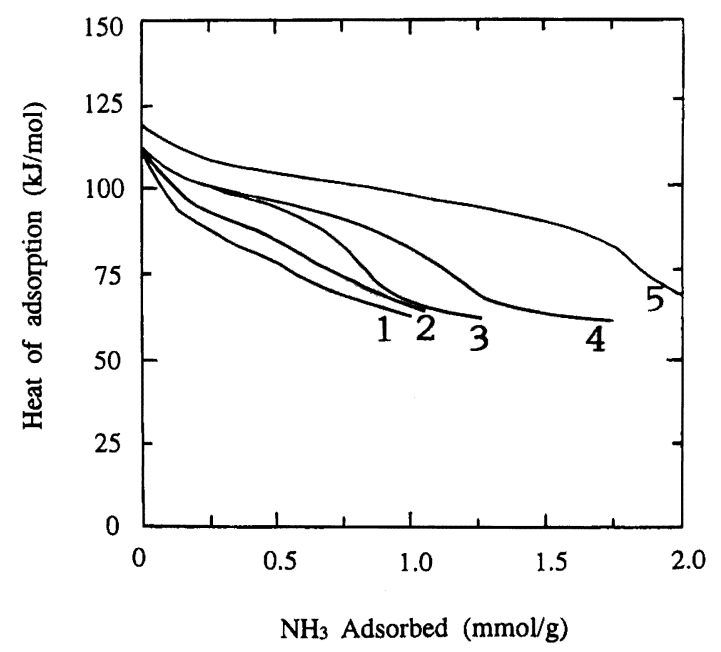

Fig. 4 Heat of adsorption as a function of ammonia coverage

1: FZ, 2: 0.2-HFZ, 3: 2.0-HFZ, 4: 0.2-NH $\mathrm{NZZ}_{4}$ : $: 2.0-$ $\mathrm{NH}_{4} \mathrm{FZ}$

Table 2 Amount of acid on chemically treated clinoptilolites $^{a)}$

\begin{tabular}{cccc}
\multirow{2}{*}{$\begin{array}{c}\text { Concentration } \\
\left(\mathrm{mol} / \mathrm{dm}^{3}\right)\end{array}$} & \multicolumn{3}{c}{$\mathrm{NH}_{3}$ adsorbed (mmol/g) } \\
\cline { 2 - 4 } & $\mathrm{HFZc)}$ & $\mathrm{NFZ}^{b)}$ & $\left.\mathrm{NH}_{4} \mathrm{FZ}^{d}\right)$ \\
\hline 0.1 & 0.53 & & 0.8 \\
0.5 & 0.56 & & 1.4 \\
1.0 & 0.67 & 1.6 \\
2.0 & 0.79 & & 1.8 \\
- & & 0.45 &
\end{tabular}

a) Measured by calorimetry at $473 \mathrm{~K}$.

b) Treated with distilled water.

c) Treated with $\mathrm{HCl}$.

d) Treated with $\mathrm{NH}_{4} \mathrm{Cl}$.

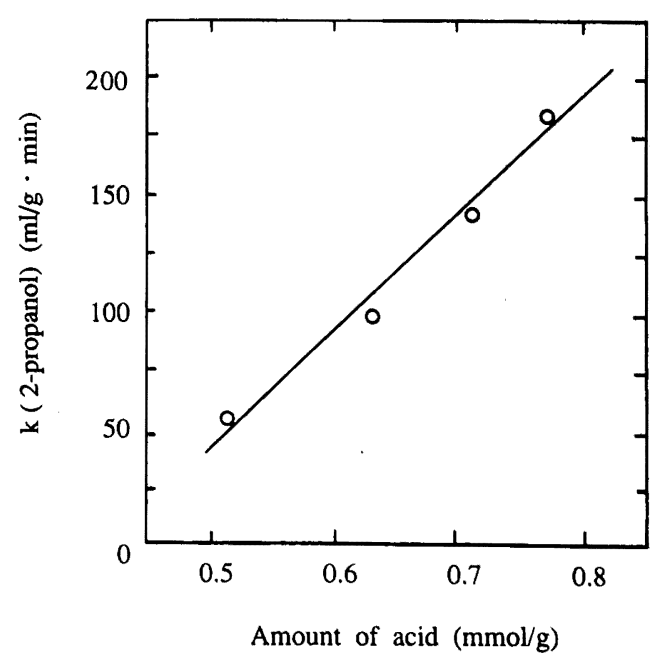

Fig. 5 Reaction rates of the dehydration of 2-propanol over $\mathrm{HFZ}$ as a function of acid amount Reaction temperature: $543 \mathrm{~K}$ 


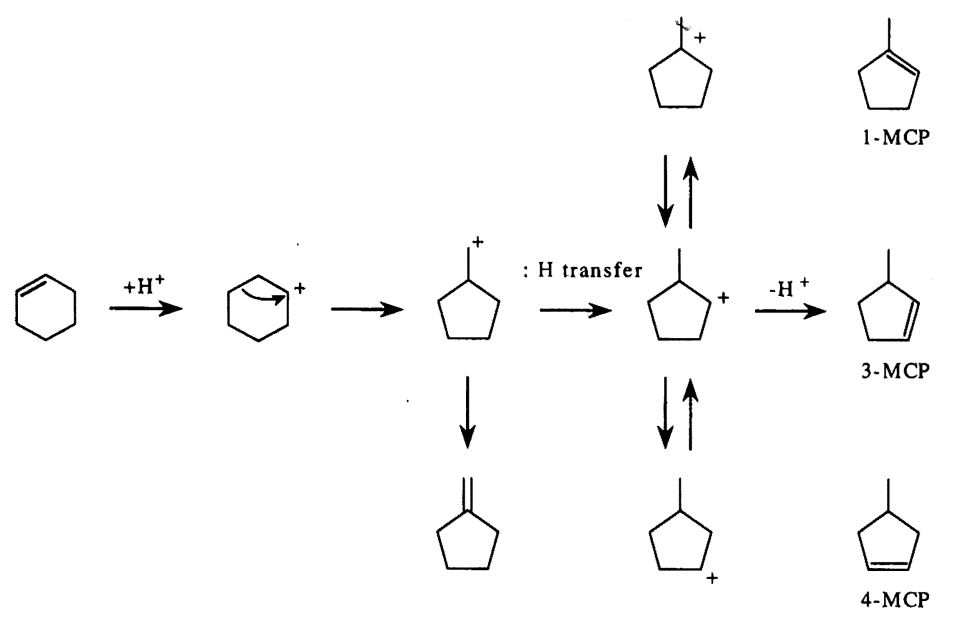

Scheme 1

異性化反応を行い，1-メチルシクロペンテン(1-MCP と略す) と 3-MCP のモル比が $7: 3$ の混合物を得て両者は容易に分離で きるとしている. Mochida ら22)はシリカアルミナ, アルカリ処 理シリカアルミナ触媒でシクロヘキセンの異性化反応を行い, Brönsted 酸点が反応を促進させるとしている．また，Pines ${ }^{23} /$ は シクロヘキサノールの脱水およびシクロヘキセンの異性化反応に 対するアルミナ触媒の作用について, Campelo ら ${ }^{24) 25)}$ はリン酸 アルミニウムでのシクロヘキセンの異性化反応についてそれぞれ 検討している.

従来, シクロへキセンの骨格異性化反応で得られる MCP は 1-MCP と 3-MCP の及と考えられていたが，四式 1 に示す反応 機構12) から 4-MCP の存在も予想される。本研究での GC(図 6) および GC/MS の検討から 4-MCP の存在と微量のメチルシクロ ペンタン(MCPH と略す) の存在が確認された。これらの平衡混

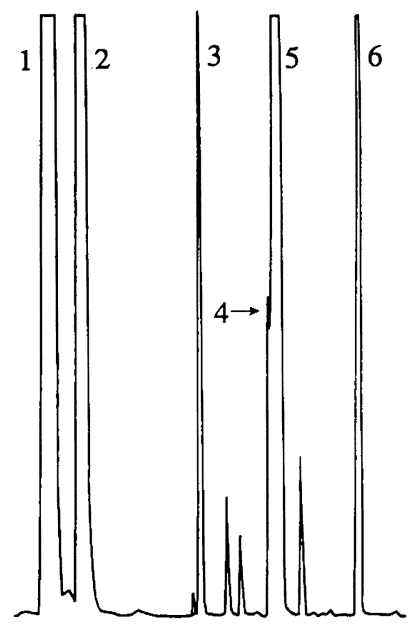

Retention time $\longrightarrow$

Fig. 6 Gas chromatogram of isomerization products

1: 3-MCP, 2: 4-MCP, 3: Methylcyclopentane, 4: Methylenecyclopentane,

5: 1-MCP, 6: Cyclohexene

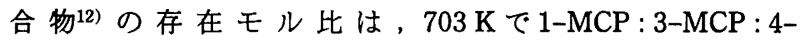
$\mathrm{MCP}=8.5: 1.0: 2.0$ であった.

3.4.2 クリノプチロライトの酸量とMCP 生成量 : 因 7 に $0.1 \sim 1.0 \mathrm{~mol} / \mathrm{dm}^{3}$ の塩酸で処理したクリノブチロライト(HFZ) を用いてのシクロへキセンの骨格異性化反応の結果, 酸量と生成 した MCP および $\mathrm{MCPH}$ 量との関係を示す. クリノプチロライ トの酸睤の增加にとむない MCP の選択性は減少し, MPCH 生 成量が增えた。

小野ら ${ }^{26)}$ は 1-ブテンの転化反応を HZSM-5, H-Borosilicate, Zn-ZSM-5 の各触蝶で検討しており，HZSM-5 上ではオレフィ ンとカルペニウムイオン間のヒドリド移行反応よって低級パラフ インと芳香族炭化水素を多く与えるが，H-Borosilicate, Zn-

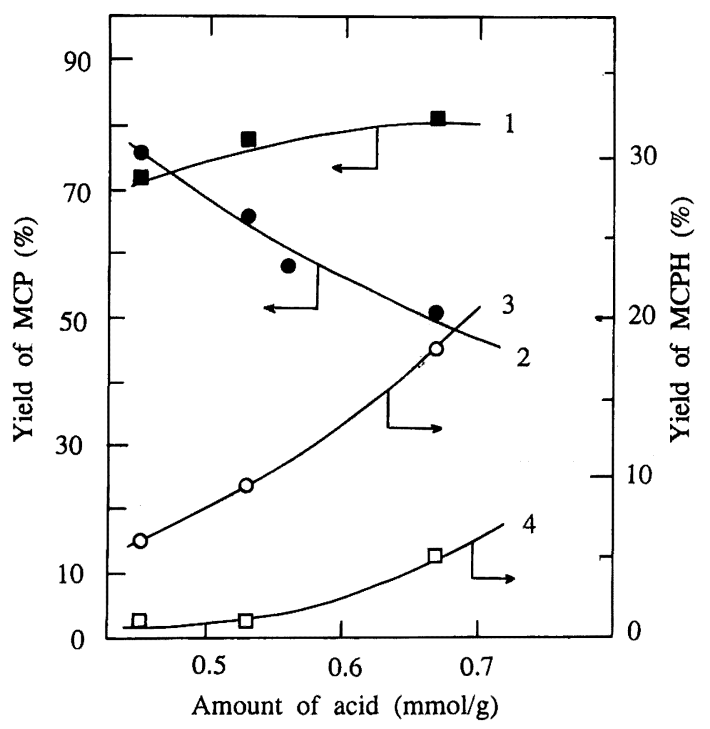

Fig. 7 Relationship between the acid amount and the yield of MCP and MCPH Catalyst: HFZ

(1): MCP produced from cyclohexanol

(2): MCP produced from cyclohexene

(3): $\mathrm{MCPH}$ produced from cyclohexene

$\square$ (4): MCPH produced from cyclohexanol 


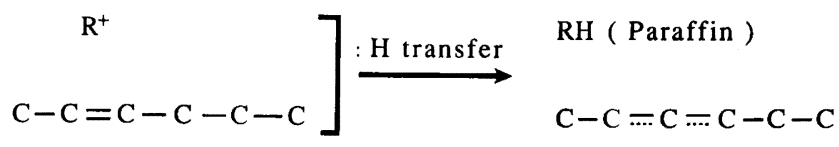

$\longrightarrow$ Aromatic hydrocarbon $\longrightarrow \longrightarrow$ Carbon

Scheme 2

ZSM-5 ではヒドリド移行が起こりにくい,としている. 図式 2 に 示すようにカルベニウムイオンとオレフィン分子からヒドリド移 行反応が起こるとパラフィンが生成し，同時に生じたアリルカル ベニウムイオンからさらにヒドリド移行反応が進行し，芳香族炭 化水素が生成する. さらに反応が繰り返されると炭素質が析出す ることが知られている27)28).

これらのことから，MCPH 生成(ないし炭素質の析出）をでき るたけ抑えて, MCP 生成の選択性を向上させるためにはアルコ 一ルの脱水で水が生じる経路, すなわちシクロへキサノールから の異性化反応が有効である (図 7)。 また, 反応操作としてはシク ロヘキセンの反応器への導入を速くして触媒との接触時間を短く すると MCPH の生成量を低く抑えることができる.

表 3 にシクロヘキセンの骨格異性化反応を行った結果を示す. 酸量の增加にともない転化率は上がるが，オレフィンである $\mathrm{MCP}$ の選択率が減少し，パラフィンである $\mathrm{MCPH}$ と芳香族炭 化水素が増大した．比較のため用いた HZSM-5 の場合は， $\mathrm{C}_{6} \sim$ $\mathrm{C}_{8}$ 芳香族炭化水素のみを与えた。 すなわち触媒の酸量の增加に ともないヒドリド移行反応に支配されていることが示唆される.

Table 3 Conversion of cyclohexene over chemically treated clinoptiolite and HZSM-5

\begin{tabular}{lrccc}
\multicolumn{1}{c}{ Catalyst } & FZ & 0.1-HFZ & 1.0-HFZ & HZSM-5 \\
\hline Conversion(\%) & 93.9 & 94.9 & 96.1 & 100 \\
Yield of MCP(\%) & 75.7 & 58.2 & 43.0 & 0 \\
Yield of MCPH(\%) & 6.0 & 11.3 & 18.3 & 0 \\
Yield of aromatics(\%) & 12.3 & 21.3 & 28.6 & 99
\end{tabular}

$\begin{array}{lcrrl} & & & \\ \mathrm{C}_{4} \sim \mathrm{C}_{5} \text { Paraffin } & \text { trace } & 0.2 & 0.4 & 0 \\ \mathrm{C}_{3} \sim \mathrm{C}_{5} \text { Olefin } & 1 & 2.5 & 3.2 & 0.2 \\ \text { 1-MCP } & 52.1 & 40.7 & 30.7 & 0 \\ \text { 3-MCP } & 12.4 & 9.7 & 7.1 & 0 \\ \text { 4-MCP } & 6.1 & 4.8 & 3.5 & 0 \\ \text { Methylenecyclopentane } & 1.4 & 1.4 & 1.0 & 0 \\ \text { MCPH } & 6 & 11.3 & 18.3 & 0 \\ \text { Aromatics } & 12.3 & 21.3 & 28.6 & 99 \\ \text { Cyclohexene } & 6.7 & 5.1 & 3.9 & 0\end{array}$

Note) Reaction temperature: $703 \mathrm{~K}$

All values were determined by $\mathrm{GC}$

Catalyst: FZ; Natural clinoptilolite

$0.1-\mathrm{HFZ}$; Treated with $0.1 \mathrm{~mol} / \mathrm{dm}^{3} \mathrm{HCl}$ 1.0-HFZ; Treated with $1.0 \mathrm{~mol} / \mathrm{dm}^{3} \mathrm{HCl}$

Product: 1-MCP; 1-Methylcyclopentene 3-MCP; 3-Methylcyclopentene 4-MCP; 4-Methylcyclopentene $\mathrm{MCPH}$; Methylcyclopentane
以上のことから, シクロヘキセンからの骨格異性化反応で MCP を合成する触媒としては，酸量(点) が適度に抑制されている $\mathrm{FZ}\left(\mathrm{Na}^{+}\right.$が残存) が有効であることがわかった。このことは, 酒 旬ら ${ }^{9)}$ および新田 ${ }^{10)}$ がメタノールから低級オレフィンを合成する 触媒としてクリノプチロライトが有効であるとした見解と関保深 い.

\section{4 結 言}

天然ゼオライトの高付加価值化とその利用という観点で，秋田 県二ツ井産の天然ゼオライト（クリノプチロライト）のキャラク タリゼーションと触媒反応を検討した. クリノブチロライトを室 温下, 低濃度の塩酸で化学処理することによりナトリウムイオン とのプロトン交換によって酸量を任意に変えられた．2-プロパ ノールの脱水反応速度は酸量に比例した. 一方, シクロヘキセン の接触熱異性化反応では酸量が増加すると, 生成するメチルシク ロペンテンとカルペニウムイオンの間でのヒドリド移行が進行す るため, パラフィンと芳香族炭化水素が増加してメチルシクロペ ンテン類の生成量が減少した．このようにきわめて廉価な天然資 源を付加価值のより高い触媒として有効利用できることが確認さ れた.

本研究の一部は, 財団法人斎藤憲三顕彰会個人研究助成金によ り行われた. 感謝申し上げます. 最後に本研究に関して有益なご 教示を戴いた上智大学理工学部瀬川幸一教授ならびに秋田大学教 育学部安倍信夫教授に深く感謝いたします。また GC/MS の測 定·解析に協力戴いた千代田化工建設株式会社山本 進氏に深謝 いたします.

（第 7 回ゼオライト研究発表会(1991年11月）および化学系 7 学 協会連合東北地方大会(1991年 9 月) でそれそれ発表した内容を 含む.）

1）鳥居一雄, ゼオライト, 1, (4), 1(1984).

2）吉田 徹, 鎌田 悟, 菅原 靖, 工藤 素, ゼオライト 9, (4), 1(1992).

3）野田修司, 第 9 回ゼオライト研究発表会, 鳥取, 講演予 稿集 (1993) p. 1.

4) E. Detrekoy, D. Kallo, Acta chim. Acad. Sci. Hung., 95, 201 (1977).

5) E. Miklosy, J. Papp, D. Kallo, Zeolites, 3, 139 (1983)

6) H. A. Gonzales, B. V. Romanovskii, K. V. Topchiva, $K i$ net. Catal., 23, 1278 (1983).

7）機 文雄, 大沢善次郎, 日化, 1984, 631.

8) H. G. Karge, H. Köster, Y. Wada, Proceedings, 6th Intern. Zeolite Confer., Butterworths (1984) p. 308.

9）酒匂春海, 新田昌弘, 青村和夫, 北海道大学工学部研究 報告, $128,69(1985)$ 
10）新田昌弘, ゼオライト, 3, (2), 13(1986).

11) G. Gottardi, E. Galli, Eds., "Natural Zeolites", Spring-Verlag (1985) p. 256; G. V. Tsitsishvili, T. G. Andronikashvili, G. N. Kirov, L. D. Filizova, Eds., "Natural Zeolites", Ellis Horwood (1992) p. 40.

12）齋藤義一，佐藤寛次，安倍信夫，有合化，36， 1064(1978).

13）林繁信, 中田真一編, “チャートで見る材料の固体 NMR"，講談社 (1993) p. 66.

14）鳥居一雄, 堀田正己, 浅賀 質, 岩石鉱物鉱床学会誌, 74, 423(1979)

15）樋野良治, 土井英徳, 岡部由紀子, 浜田賢作, 藤原隆二, 日化, 1989,435 .

16）瀬川幸一, 坂口美夏, 中田真一, 浅岡佐知夫, 日化, $1989,529$.

17）中田真一, 化学工業, 41, 354(1990).

18) S. Nakata, S. Asaoka, T. Kondoh, H, Takahashi, Stud.
Surf. Sci. Catal., 28, 71(1986).

19）中田真一, ゼオライト, 10, (4), 16(1993).

20）あらかじめ吸脱着の検討を行い，アンモニアの物理吸着 と化学吸着の識別をしている.

21) H. Adkins, A. K. Roebuck, J. Am. Chem. Sci., 70, 4041 (1948).

22) I. Mochida, Y. Yoneda., J. Catal., 7, 393(1967).

23) H. Pines, J. Catal., 78, 1(1982).

24) J. M. Campelo, A. Garcia, D. Luna, J. M. Marinas, J. Catal., 102, 299(1986).

25) J. M. Campelo, A. Garcia, D. Luna, J. M. Marinas, React. Kinet. Catal. Lett., 30, 165(1986).

26) Y. Ono, H. Kitagawa, Y. Dendoda, J. Chem. Soc., Faraday Trans. 1, 1987, 2113

27）小野嘉夫, 触媒, 29, 253(1987).

28）服部 英, 多田旭男, 菊地英一, 瀬川幸一, 射水雄三編, “新しい触媒化学”，三共出版 (1988) p. 40.

\section{Characterization of Natural Clinoptilolites and Skeletal Isomerization of Cyclohexene}

\section{Masayuki NomURA, Giichi SAITO ${ }^{\dagger}$, Shin-ichi NAKATA*+† and Yasuo MORIMURA ${ }^{\text {t+ }}$}

Odade Homei Senior High School; Kanezaka-ushiro 6, Odade-shi 017 Japan

${ }^{\dagger}$ Department of Education, Akita University; Tegatagakuen-cho 1-1, Akita-shi 010 Japan

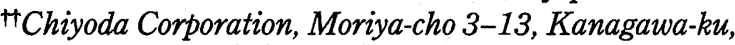
Yokohama-shi 221 Japan

From the point of view of the effective utilization as high additional value of natural sedimentary zeolites, characterization and catalytic reaction tests have been made. The samples in this study was natural clinoptilolite (FZ) produced in Futatsui, Akita Prefecture, and its specimens (HFZ) chemically treated with hydrochloric acid in various concentrations.

Identification of clinoptilolite and investigation of crystallinities were made by X-ray diffraction. Structural analysis of microenvironments of zeolitic framework was made by high-resolution solid-state MASNMR. The amount of solid acid of zeolite surface was determined by micro-calorimetry of $\mathrm{NH}_{3}$ adsorption at $473 \mathrm{~K}$.

As the concentration of hydrochloric acid is increased, the $\mathrm{Si} / \mathrm{Al}$ atomic ratio of zeolites increased. The reaction rates on dehydration of 2-propanol over HFZ was proportional to the acid amount. On the skeletal isomerization reaction of cyclohexene into methylcyclopentenes over HFZ, as the concentration of hydrochloric acid increased, the yields of methylcyclopentane and aromatic hydrocarbons increased, while the yield of methylcyclopentenes decreased. The reaction over HZSM-5 gave only aromatic hydrocarbons. 